
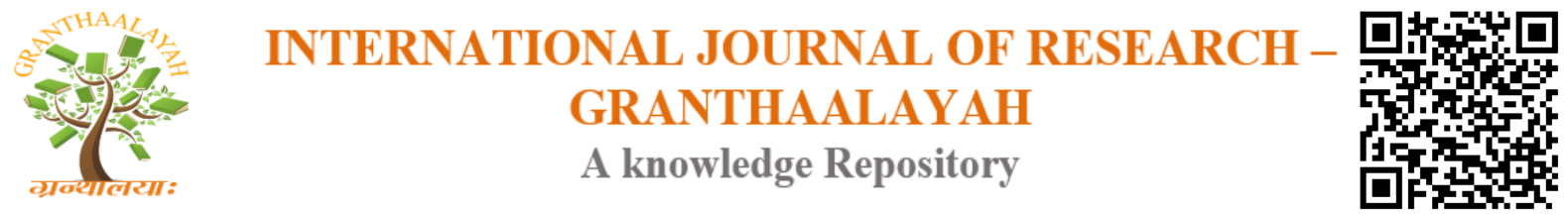

Management

\title{
THE IMPACT OF MICROFINANCE BANKS IN RURAL AREAS OF SUB- SAHARAN AFRICA
}

\author{
Isabelle Musanganya ${ }^{* 1}$, Chantal Nyinawumuntu ${ }^{2}$, Pauline Nyirahagenimana ${ }^{3}$ \\ ${ }^{* 1,3}$ Catholic Institute of Kabgayi, Faculty of Social, Economics Sciences and Management, \\ Kigali City, PO. Box 62 Rwanda \\ ${ }^{2}$ Beijing Jiaotong University, School of Economics and Management, Department of Logistics \\ and Engineering, Haidian District, Beijing 100044, China
}

\begin{abstract}
Many researchers consider microfinance as a tool for poverty reduction. Even more, especially in post-conflict African countries, micro-financial institutions are seen as an opportunity of reconciliation. Lending from microfinance institutions to that from traditional banks and examine their respective effects upon economic growth has been practiced in some sub-Saharan countries. Considerable progress in research has been found that microfinance loans raise growth comparatively to that of traditional banks. A lot of number of researches carried out in subSaharan countries even in other developing countries outside of Africa did not find strong evidence that bank loans raise growth. There is, however, some evidence that bank loans do increase investment, whereas microfinance loans do not appear to do so. Differently, other researchers highlighted clearly that microfinance can provide its contribution on poverty reduction and better access to finance needed for startup micro-entrepreneurs along the world. These results suggest that microfinance loans are not primarily invested as physical capital in developing countries, but could still augment total factor productivity, whereas banks may have been financing non-productive investments. Herein, we highlighted the impact of microfinance banks on developing countries economic growth. We also indicate how microfinances system incorporated in rural areas boosted the lifestyle of poor people in Sub-Saharan Africa.
\end{abstract}

Key words: Microfinance; Micro-Credit; Micro-Savings; Developing Countries; Poverty; Impact.

Cite This Article: Isabelle Musanganya, Chantal Nyinawumuntu, and Pauline Nyirahagenimana. (2017). "THE IMPACT OF MICROFINANCE BANKS IN RURAL AREAS OF SUBSAHARAN AFRICA." International Journal of Research - Granthaalayah, 5(9), 80-90. https://doi.org/10.29121/granthaalayah.v5.i9.2017.2201.

\section{Introduction}

Food security and poverty reduction remain major development objectives in sub-Saharan Africa (SSA) as well as two major Sustainable Development Goals. Since the beginning of the 2000s, all development projects in SSA, one of the poorest regions in the word, have directly or 
indirectly targeted these two objectives (Ozturk, 2017). The World Bank (2016) estimated that about 389 million persons out of 904 million in SSA, corresponding to $43 \%$ of the population, live under the poverty line of US\$ 1.90 per day. Poverty in SSA is predominantly rural as more than $70 \%$ of poor people live in rural areas and depend on agriculture for their food and livelihood (IFAD, 2012). SSA has the highest prevalence of hunger in the world and in 2012 and 2014 , about $25 \%$ and $22 \%$ of the population, respectively, were food insecure. Moreover, the per-capita consumption of more than 239 million persons is estimated to be below the food energy target of 2100 food calories per day (Arouna, Lokossou, Wopereis, Bruce-Oliver, \& RoyMacauley, 2017). Under such situations, SSA is still prone to social instability, which could be a similar recurrence of the food crises that was observed in several African countries in 2008. Sustainable agricultural growth is, therefore, considered as the most appropriate pathway to longterm and pro-poor economic development in SSA (Diao, Hazell, \& Thurlow, 2010; Mazumder \& $\mathrm{Lu}, 2015)$. A radical change in microfinance practices and related socioeconomic and political systems is essential (Bos \& Millone, 2015). Traditional finance systems, oriented towards commercial banks and local trade, have to change and support of small enterprises in order to increase both production and income (Wijesiri, 2016). Policy makers, donors, and other development partners have developed and implemented several strategies over the years, including boosting the microfinance sector, which has been identified as a vital component of development and poverty alleviation (Jia, Cull, Guo, \& Ma, 2016). Microfinances are rapidly gaining in importance as a staple tool and is now one of the largest sources of development in SSA (Tchakoute Tchuigoua, 2015). It represents the basic food for more than 750 million persons in SSA (Ahmeti, 2014). The objective of this review is to assess the contribution of microfinances to improving development and reducing poverty in SSA. A review of impact assessment studies on impact of microfinances in SSA since the beginning of the 2000s and an analysis of recent household-level data have been carried out. The contribution of this review to existing literature is threefold. Firstly, according to development theories, rural lifestyle transformation will follow an impact pathway wherein the adoption of microfinance is expected to improve lifestyle. Although existing literature indicate the positive impact of microfinances on nation income(Hermes \& Lensink, 2011), many studies have not revealed how the observed increase in income has come about. This review fills this gap in the literature by estimating the impact of microfinances along the impact pathway by taking into consideration the following six outcomes: yield, production, stakeholder's income, stakeholder's expenditure, poverty headcount ratio, and country development. Secondly, we empirically show whether MFIs can have economy-wide effects and, specifically, upon the economic growth rate. In addition, although previous studies have estimated the impact of microfinances on poverty, to our knowledge, none of them have clearly estimated the number of people lifted out of poverty and food insecurity, due to the involvement in microfinances as saving and credits tool (Adams, Graham, \& Von Pischke, 1984; van Rooyen, Stewart, \& de Wet, 2012). This review reveals the consistency of literature on impact assessment of microfinances and checks the hypothesis that application of microfinances in rural areas play an important role in Nation development.

\subsection{Microfinances}

The term "microfinance" has been known as a provision of micro loan to the poor entrepreneurs and small businesses lacking access to banking and related services. The two main mechanisms for the delivery of financial services to such clients were: (1) relationship-based banking for 
individual entrepreneurs and small businesses; and (2) group-based models, where several entrepreneurs come together to apply for loans and other services as a group.

Over time, microfinance has emerged as a larger movement whose object is "a world in which as everyone, especially the poor and socially marginalized people and households have access to wide range of affordable, high quality financial products and services, including not just credit but also savings, insurance, [(payment services)], and fund transfers"(Adams et al., 1984). Many of those who promote microfinance generally believe that such access will help poor people out of poverty, including participants in the Microcredit Summit Campaign. For many, microfinance is a way to promote economic development, employment and growth through the support of micro-entrepreneurs and small businesses; for others it is a way for poor to manage their finances more effectively and take advantage of economic opportunities while managing the risks. The terms have evolved from microcredit to microfinance, and now 'financial inclusion'.

Microfinance is a broad category of services, which includes microcredit. Microcredit is only about provision of credit services to poor clients; only one of the aspects of [(microfinance)], and the two are often confused. Critics often point to some of the ills of micro-credit that can create indebtedness. Due to diverse contexts in which microfinance operates, and the broad range of microfinance services, it is neither possible nor wise to have a generalized view of impacts Microfinance may create. Many studies have tried to assess its impacts. ${ }^{[2]}$ Proponents often claim that microfinance lifts people out of poverty, but the evidence is mixed. What it does do, however, is to enhance financial inclusion.

\section{An Overview of Some Research Findings}

Since the late 1970s, microfinance has come to be seen as an integral part of developmental policy and an effective poverty reduction tool. (McIntosh, Villaran, , \& Wydick, 2011) argued that microfinance is a key tool for achieving MDGs, and microfinance has been shown to have an impact on recipients' income, savings, expenditure, and the accumulation of assets, as well as non-financial outcomes including health, nutrition, food security, education, child labor, housing job creation, and social cohesion (McIntosh, Villaran, \& Wydick, 2011b). Microfinance can also have a positive impact on recipients' livelihoods as defined by their basic rights and their quality of life (poverty level) (Johnson et al., 2009).

\subsection{An Overview of the Impact of Microfinance on Basic Rights}

Microfinance client households appear to have better nutrition, living conditions, and preventative healthcare than non-client households. Littlefield et al. (2003) reported that severe malnutrition declined with increased length of microfinance membership in Bangladesh, in part due to smoothening expenditures and allowing more constant access to food. Microfinance improves health and nutrition knowledge and practice and ultimately improves household food security and children's nutritional status (McIntosh, Villaran, \& Wydick, 2011a). Clothing is another basic need; Ghalib, Malik, and Katsushi (2012) found that there were few significant differences between microfinance groups with respect to changes in household expenditure on clothing (Ghalib, 2007). Mknelly and Dunfond (2000) also noted that there were few significant differences across study and control groups in charge of household expenditures on food, 
clothing, medicine, school expenses, and house repair or business assets (Mknelly \& Dunford, 2000). McIntosh, Villaran, and Wydick (2011) noted that access to credit is associated with moderate increases in variables associated with household welfare.

Although microfinance intervention does not directly influence clients' level of education, it has been shown to have a positive impact on the education of clients' children, with children of microfinance clients more likely to go to school and stay there for longer than the children of non-clients (Littlefield, Morduch, \& Hashemi, 2003). Chowdhury and Bhuiya (2004) noted that student dropout rates were much lower in microfinance client households than in non-client households. Chowdhury and Bhuiya (2001) also concluded that MFI client households appear to have better nutrition, living conditions, and preventive health- care than non-client households. There is therefore conflicting evidence on the effect of microfinance on basic rights, and the effect of the provider (i.e., GO or NGO) is uncertain, since to date there have been no studies directly comparing the impact of GO and NGO microfinance programs on recipients' basic rights using a comparison with non-recipient groups.

\subsection{An Overview of the Impact of Microfinance on Quality of Life (Poverty Status)}

Kan, Olds, and Kah (2005) studied the evolution, sustain ability, and management of ten microfinance institutions in Gossas, Senegal and found that while microfinance institutions have helped to create a positive change, there was still no clear and marked evidence of poverty reduction that was attributable to the microfinance programs studied (Kan, Olds, \& Kah, 2005). Morris and Barnes (2005) attempted to provide an overall assessment of the impact of three microfinance programs in Uganda; they also found no clear evidence of poverty reduction in the pro-gram areas, although there was some positive impact on participants' entrepreneurial business endeavors, in their households, and in reducing the financial vulnerability of poor individuals through diversification of available income sources and the accumulation of assets (Morris, 2005). Schroeder (2012) concluded that microcredit is reducing poverty in Rwanda by allowing households to raise their levels of consumption, and Nawaz (2010) found that microfinance has resulted in a moderate poverty (Nawaz, 2010). In contrast, Leo and Alfred (2010) showed that microfinance does not have a large impact on client well-being. There is therefore conflicting evidence with respect to the impact of microfinance on quality of life (poverty level) (Leo \& Alfred, 2010). Most of the existing research on MFIs has, therefore, focused on the impact of microfinance on alleviation of poverty based on a single financing organization. All of these studies attempted to establish a link between microfinance and rural livelihood, but to date no study has been undertaken that considers both GOs and NGOs as the implementing authorities with non-recipient respondents as the control group. 


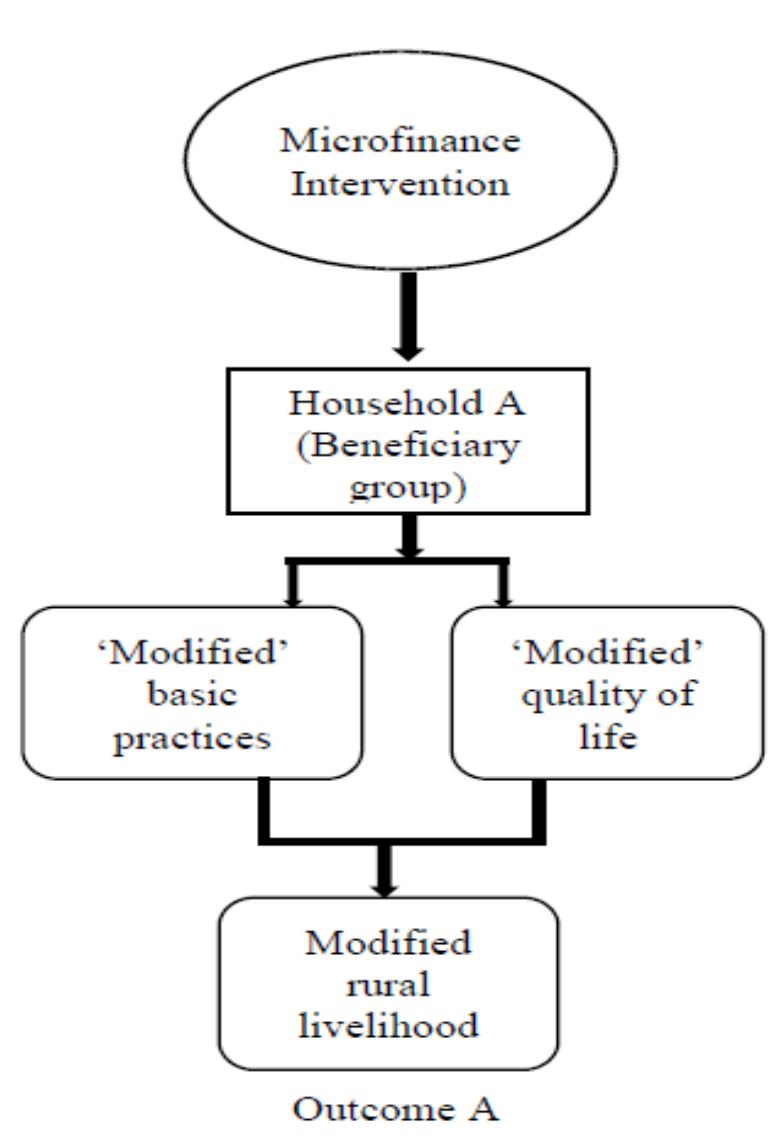

DOI: $10.5281 /$ zenodo.999246

Figure 1: A schematic representation showing how the presence of microfinance can impact on rural livelihoods

\subsection{Microfinances Impact on Economic Growth}

Over the last decade, microfinance has increased sharply, albeit from a small base. From 2002 to 2013 , the total loan portfolio of MFIs (in all developing countries) increased from $\$ 4.95$ to $\$ 144.70$ billion. Over the same period, total deposits have also increased from $\$ 8.2$ million to $\$ 86.54$ billion. In addition, the numbers of borrowers and depositors have increased likewise. Despite these increases, bank lending and deposits still constitute the main components of such activities. Kendall, Mylenko, and Ponce (2010) shed some light on the intermediation by financial intermediaries. They use 139 countries, including 21 OECD countries, to calculate the number of bank accounts in the world at 6.2 billion. Obviously, the distribution is skewed toward the rich countries, which account for 3.2 accounts per adult with $81 \%$ of adults banked, whereas developing countries account for only 0.9 accounts per adult and only $28 \%$. In addition, loan penetration in commercial banks and MFIs are respectively 299 and 7.9 loans per one thousand adults, whereas the average deposit balance is 2.6 versus 0.8 times GDP per capita. Given that bank lending is larger and serves more people than MFI lending, one wonders if microfinance institutions are even large enough to influence economic growth at the aggregate level. Moreover, regulations often limit the number that MFIs can lend. For instance, in Nigeria, a microfinance bank is not allowed to lend out more than 500,000 nairas (about \$3100) to a single individual or business. Nevertheless, the reason for the growth of MFIs has been the lack of bank lending to those from poor, often rural communities. If the macroeconomic benefits of lending to 
such agents are relatively large since these agents have the highest growth potential, then such lending could serve as a catalyst for growth despite their relative small size. Lopatta and Tchikov (2016) report that microfinance directly influences economic growth through the value their performance adds to purchasing power and indirectly through capital accumulation and employment (Lopatta \& Tchikov, 2016).

Positive spillovers are also found at the village level as even non-borrowers benefit from the increased demand of borrowers. Tarozzi, Desai, and Johnson (2015) use a randomized controlled trial in two communities in Ethiopia and find that access to microfinance improves the standard of living for beneficiary communities, although they caution microfinance's true transformative power. Although they do not find evidence of spillovers, Lønborg and Rasmussen (2014) do find that microfinance participants are less poor than the general population in the area. They also find that microfinance increases food consumption and per capita income. Berhane and Gardebroek (2011) consider microfinance in northern Ethiopia and find that microfinance facilitates borrowers to increase their consumption while also making home advancement. Similar results also were reported (Agbola, Acupan, \& Mahmood, 2017). Raihan, Selim Osmani, Khalily, Baqui (2017) find that microcredit programs continue to be beneficial in Nigeria, especially for females (Raihan, Osmani, \& Khalily, 2017). Other researchers have considered various other effects of MFIs. Wijesiri, Mahinda Meoli and Michele (2015) survey customers of a village bank in Kenya and concluded that MFIs are responsible for the increase by $40 \%$ in saving accounts for businesswomen, as well as in their consumption (Wijesiri \& Meoli, 2015). Odongo and Lilian (2013) shows that high interest rates increase the odds of client delinquency while loan size is inversely related to delinquency. They proposed that policymakers need to work for stability in the macro-environment to ensure interest rates charged by microfinance institutions (MFIs) remain stable and affordable (Kodongo \& Kendi, 2013). In Sub-Saharan Africa, Stewart, Van Rooyen, Dickson, Majoro, and De Wet (2010) review MFIs' effects and report that MFIs have a positive effect on savings, expenditure, health and food security, and asset accumulation. Michael and Albert (2016) explore how informal microfinance institutions (IMFIs) support development-led tourism entrepreneurship through providing microcredit and development opportunities to small tourism firms (STFs), as well as undertaking communitarian projects and outreach activities that promote the business activities of STFs in Cameroon (Ngoasong \& Kimbu, 2016). Using panel data and household fixed-effects, they run two regressions with the level and the change in the level of the dependent variables to examine the effect of the program on credit, savings and investment, consumption, asset growth, income and income sources, wage rates, and business enterprise. The results indicate that the intervention has increased short-term credit, consumption, investment in agriculture, and income growth but decreased asset growth. More importantly, the intervention increased village-level wages. Such positive spillovers could be one reason why the benefits of microfinance could be measured above the local level. However, not all see microfinance as a strong tool in raising income and reducing poverty (Coleman, 2006).

Babajide (2012) does not find a positive effect of receiving microcredit upon micro and small firms in Nigeria. 
Table 1: Some developing countries with their corresponding microfinances impact on rural sectors

\begin{tabular}{|c|c|c|c|}
\hline $\begin{array}{l}\text { Country and } \\
\text { typical area }\end{array}$ & Microfinance intervention & Microfinance model & Ref. \\
\hline $\begin{array}{l}\text { Rural and urban } \\
\text { setting in Ghana }\end{array}$ & $\begin{array}{l}\text { Credit with business } \\
\text { management training \& client } \\
\text { welfare scheme }\end{array}$ & $\begin{array}{l}\text { Group-based lending } \\
\text { to men and women }\end{array}$ & $\begin{array}{l}\text { (Adjei, Arun, } \\
\text { \& Hossain, } \\
\text { 2009) }\end{array}$ \\
\hline Rural Kenya & $\begin{array}{l}\text { Credit with orientation course \& } \\
\text { advice on export crops and } \\
\text { facilitation of export process }\end{array}$ & $\begin{array}{l}\text { Group-based lending } \\
\text { to small } \\
\text { holder farmers }\end{array}$ & $\begin{array}{l}\text { (Ashraf, Gine, } \\
\text { \& Karlan, } \\
\text { 2008) }\end{array}$ \\
\hline $\begin{array}{l}\text { Rural and urban } \\
\text { setting in } \\
\text { Uganda }\end{array}$ & $\begin{array}{l}\text { Credit and savings with non- } \\
\text { formal education in health, } \\
\text { nutrition, family planning, HIV/ } \\
\text { Aids prevention \& business } \\
\text { management }\end{array}$ & $\begin{array}{l}\text { Group-based lending } \\
\text { to men and women }\end{array}$ & $\begin{array}{l}\text { (Barnes, } \\
\text { Gaile, \& } \\
\text { Kibombo, } \\
\text { 2001) }\end{array}$ \\
\hline $\begin{array}{l}\text { Urban } \\
\text { Zimbabwe }\end{array}$ & $\begin{array}{l}\text { Credit with business } \\
\text { management training }\end{array}$ & $\begin{array}{l}\text { Group and individual } \\
\text { lending to } \\
\text { men and women }\end{array}$ & $\begin{array}{l}\text { (Barnes \& } \\
\text { Keogh, 1999) }\end{array}$ \\
\hline Rural Swaziland & $\begin{array}{l}\text { Credit and saving at the local } \\
\text { level }\end{array}$ & Adult people & $\begin{array}{l}\text { (allafrica.com } \\
\text {, 2009) }\end{array}$ \\
\hline $\begin{array}{l}\text { Rural Tanzania } \\
\text { (Zanzibar) }\end{array}$ & $\begin{array}{l}\text { Credit and savings with business } \\
\text { training }\end{array}$ & $\begin{array}{l}\text { Group-based lending } \\
\text { to men and } \\
\text { women }\end{array}$ & $\begin{array}{l}\text { (Brannen, } \\
\text { 2010) }\end{array}$ \\
\hline Rural Ethiopia & Credit & $\begin{array}{l}\text { Group-based lending } \\
\text { to men and } \\
\text { women }\end{array}$ & $\begin{array}{l}\text { (Doocy, } \\
\text { Teffera, } \\
\text { Norell, \& } \\
\text { Burnham, } \\
\text { 2005) }\end{array}$ \\
\hline Rural Kenya & $\begin{array}{l}\text { Savings with scope to purchase } \\
\text { shares }\end{array}$ & $\begin{array}{l}\text { Individual savings } \\
\text { accounts }\end{array}$ & $\begin{array}{l}\text { (Dupas \& } \\
\text { Robinson, } \\
2008)\end{array}$ \\
\hline $\begin{array}{l}\text { Urban } \\
\text { Madagascar }\end{array}$ & Credit & $\begin{array}{l}\text { Group-based lending } \\
\text { to men and } \\
\text { women }\end{array}$ & $\begin{array}{l}\text { (Gubert \& } \\
\text { Roubaud, } \\
2005)\end{array}$ \\
\hline Rural Rwanda & Credit & $\begin{array}{l}\text { Group-based lending } \\
\text { to men and } \\
\text { women }\end{array}$ & $\begin{array}{l}\text { (Lacalle } \\
\text { Calderon, } \\
\text { Rico Garrido, } \\
\text { \& Duran } \\
\text { Navarro, } \\
2008 \text { ) }\end{array}$ \\
\hline Rural Uganda & $\begin{array}{l}\text { Credit with training in } \\
\text { microenterprise skills and } \\
\text { business counseling }\end{array}$ & $\begin{array}{l}\text { Group-based lending } \\
\text { to men and women }\end{array}$ & $\begin{array}{l}\text { (Lakwo, } \\
\text { 2006) }\end{array}$ \\
\hline
\end{tabular}




\begin{tabular}{|c|c|c|c|}
\hline Rural Ghana & $\begin{array}{l}\text { Credit with financial literacy } \\
\text { training }\end{array}$ & $\begin{array}{l}\text { Individual lending to } \\
\text { women }\end{array}$ & (Nanor, 2008) \\
\hline $\begin{array}{l}\text { Rural South } \\
\text { Africa }\end{array}$ & $\begin{array}{l}\text { Credit with gender and HIV/ } \\
\text { awareness training [Sisters for } \\
\text { Life] and community } \\
\text { mobilization support }\end{array}$ & $\begin{array}{l}\text { Group-based lending } \\
\text { to men and } \\
\text { women }\end{array}$ & $\begin{array}{l}\text { (Pronyk et al., } \\
\text { 2008) }\end{array}$ \\
\hline Rural Malawi & $\begin{array}{l}\text { Credit with financial literacy } \\
\text { training }\end{array}$ & $\begin{array}{l}\text { Group and individual } \\
\text { lending to } \\
\text { men and women }\end{array}$ & $\begin{array}{l}\text { (Shimamura } \\
\text { \& Lastarria- } \\
\text { Cornhiel, } \\
\text { 2009) }\end{array}$ \\
\hline Rural Uganda & $\begin{array}{l}\text { Savings dedicated to paying for } \\
\text { post-primary schooling, } \\
\text { alongside training and } \\
\text { mentorship programs }\end{array}$ & $\begin{array}{l}\text { Individual savings } \\
\text { accounts for } \\
\text { young people (boys } \\
\text { and girls) }\end{array}$ & $\begin{array}{l}\text { (Ssewamala et } \\
\text { al., 2010) }\end{array}$ \\
\hline $\begin{array}{l}\text { Rural and urban } \\
\text { setting in } \\
\text { Uganda }\end{array}$ & $\begin{array}{l}\text { Credit with various other } \\
\text { unspecified programs }\end{array}$ & $\begin{array}{l}\text { Group and individual } \\
\text { lending to } \\
\text { men and women }\end{array}$ & $\begin{array}{l}\text { (Wakoko, } \\
\text { 2004) }\end{array}$ \\
\hline
\end{tabular}

\section{Conclusion}

The rise in microfinance over the last decade has led different researchers to compare the macroeconomic effects of microfinance with those of traditional banks. Macroeconomic indicators: economic growth and investment were used in this regard. As indicated in this review, microfinance banks credit are often found to increase economic growth, whereas far less evidence arises that banking lending raises growth. To our knowledge, the positive effects of microfinance upon growth are consistent with findings from different other studies. Evidence arises that microfinance effect upon growth works through increasing TFP (Total factor productivity). Moreover, the credit generating aspect of microfinance banks appears to be more important in raising growth than is microfinance banks role of deposit taking. Second, though bank lending does not shows strong evidence of a growth effect in some Sub-Sahara Africa, it does show some evidence of an investment effect, contrary to microfinance. Thus, bank credits may have a stronger impact in spurring investment than microfinance. The implication is that microfinance loans may augment growth in other ways than by increasing physical capital. These facts reviewed provided added weight to arguments supporting the promotion of microfinance in developing countries. We can emphasize again, however, that microfinance should not be considered as a panacea to spurring growth given the fact that the economic magnitude of their effect is small.

\section{References}

[1] Adams, D. W., Graham, D. H., \& Von Pischke, J. D. (1984). UNDERMINING RURAL DEVELOPMENT WITH CHEAP CREDIT. Westview Press.

[2] Adjei, J. K., Arun, T., \& Hossain, F. (2009). THE ROLE OF MICROFINANCE IN ASSET BUILDING AND POVERTY REDUCTION: THE CASE OF SINAPI ABA TRUST OF GHANA. Manchester, Brooks World Poverty Institute. 
[3] Agbola, F. W., Acupan, A., \& Mahmood, A. (2017). DOES MICROFINANCE REDUCE POVERTY? NEW EVIDENCE FROM NORTHEASTERN MINDANAO, THE PHILIPPINES. Journal of Rural Studies, 50, 159-171. doi:10.1016/j.jrurstud.2016.11.005

[4] Ahmeti, F. (2014). MICROFINANCE AS A TOOL FOR ECONOMIC DEVELOPMENT IN TRANSITIONAL COUNTRIES: EXPERIENCE FROM KOSOVO. European Scientific Journal, 10(4), 1-19.

[5] Allafrica.com. (2009). Swaziland. http://allafrica.com.

[6] Arouna, A., Lokossou, J. C., Wopereis, M. C. S., Bruce-Oliver, S., \& Roy-Macauley, H. (2017). CONTRIBUTION OF IMPROVED RICE VARIETIES TO POVERTY REDUCTION AND FOOD SECURITY IN SUB-SAHARAN AFRICA. Global Food Security, 14, 54-60. doi:10.1016/j.gfs.2017.03.001

[7] Ashraf, N., Gine, X., \& Karlan, D. (2008). FINDING MISSING MARKETS (AND A DISTURBING EPILOGUE): EVIDENCE FROM AN EXPORT CROP ADOPTION AND MARKETING INTERVENTION IN KENYA. Washington, DC, World Bank.

[8] Barnes, C., Gaile, G., \& Kibombo, R. (2001). THE IMPACT OF THREE MICROFINANCE PROGRAMS IN UGANDA. Washington, DC, Development Experience Clearinghouse, USAID.

[9] Barnes, C., \& Keogh, E. (1999). AN ASSESSMENT OF THE IMPACT OF ZAMBUKO'S MICRO-ENTERPRISE PROGRAM IN ZIMBABWE: BASELINE FINDINGS. Washington, DC, Management Systems International.

[10] Bos, J. W. B., \& Millone, M. (2015). PRACTICE WHAT YOU PREACH: MICROFINANCE BUSINESS MODELS AND OPERATIONAL EFFICIENCY. World Development, 70, 28-42. doi:10.1016/j.worlddev.2014.12.018

[11] Brannen, C. (2010). AN IMPACT STUDY OF THE VILLAGE SAVINGS AND LOAN ASSOCIATION (VSLA) PROGRAM IN ZANZIBAR, TANZANIA. BA Dissertation, Wesleyan University.

[12] Coleman, B. E. (2006). MICROFINANCE IN NORTHEAST THAILAND: WHO BENEFITS AND HOW MUCH? World Development, 34(9), 1612-1638. doi:10.1016/j.worlddev.2006.01.006

[13] Diao, X., Hazell, P., \& Thurlow, J. (2010). THE ROLE OF AGRICULTURE IN AFRICAN DEVELOPMENT. World Development, 38(10), 1375-1383. doi:10.1016/j.worlddev.2009.06.011

[14] Doocy, S., Teffera, S., Norell, D., \& Burnham, G. (2005). CREDIT PROGRAM OUTCOMES: COPING CAPACITY AND NUTRITIONAL STATUS IN THE FOOD INSECURE CONTEXT OF ETHIOPIA. Social Science and Medicine, 60(10), 2371-2382.

[15] Dupas, P., \& Robinson, J. (2008). SAVINGS CONSTRAINTS AND MICROENTERPRISE DEVELOPMENT: EVIDENCE FROM A FIELD EXPERIMENT IN KENYA (WORKING PAPER NO 14693). Cambridge MA, National Bureau of Economic Research.

[16] halib, A. K. (2007). MEASURING THE IMPACT OF MICROFINANCE INTERVENTION: A CONCEPTUAL FRAMEWORK OF SOCIAL IMPACT ASSESSMENT. Singapore Economic Review Conference, 15-17.

[17] Gubert, F., \& Roubaud, F. (2005). ANALYSER L'IMPACT D'UN PROJET DE MICROFINANCE: L'EXEMPLE D'ADE'FI A' MADAGASCAR. Paris: DIAL (Developpement Institutions et Analyses de Long terme)

[18] Hermes, N., \& Lensink, R. (2011). MICROFINANCE: ITS IMPACT, OUTREACH, AND SUSTAINABILITY. World Development, 39(6), 875-881. doi:10.1016/j.worlddev.2009.10.021

[19] Jia, X., Cull, R., Guo, P., \& Ma, T. (2016). COMMERCIALIZATION AND MISSION DRIFT: EVIDENCE FROM A LARGE CHINESE MICROFINANCE INSTITUTION. China Economic Review, 40, 17-32. doi:10.1016/j.chieco.2016.05.007

[20] Kan, J. M. L., Olds, D. L., \& Kah, M. M. O. (2005). MICROCREDIT, SOCIAL CAPITAL, AND POLITICS. Journal of Microfinance, 7, 1121-1115. 
[21] Kodongo, O., \& Kendi, L. G. (2013). INDIVIDUAL LENDING VERSUS GROUP LENDING: AN EVALUATION WITH KENYA'S MICROFINANCE DATA. Review of Development Finance, 3(2), 99-108. doi:10.1016/j.rdf.2013.05.001

[22] Lacalle Calderon, M., Rico Garrido, S., \& Duran Navarro, J. (2008). ESTUDIO PILOTO DE EVALUACION DE IMPACTO DEL PROGRAMA DE MICROCREDITOS DE CRUZ ROJA ESPANOLA EN RUANDA. Revista de Economia Mundial, 19, 83-104.

[23] Lakwo, A. (2006). MICROFINANCE, RURAL LIVELIHOODS, AND WOMEN'S EMPOWERMENT IN UGANDA. (AFRICAN STUDIES CENTRE RESEARCH REPORT NO 85). (Ph.D.Thesis), Radboud Universiteit, Nijmegen.

[24] Leo, H., \& Alfred, L. (2010). RETHINKING THE IMPACT OF MICROFINANCE IN AFRICA: BUSINESS CHANCE OR SOCIAL EMANCIPATION. European Journal of Development Research, 22, 529-545.

[25] Littlefield, E., Morduch, J., \& Hashemi, S. (2003). IS MICROFINANCE AN EFFECTIVE STRATEGY TO REACH THE MILLENNIUM DEVELOPMENT GOALS? FOCUS NOTE 24, CGAP. Washington, DC, World Bank.

[26] Lopatta, K., \& Tchikov, M. (2016). DO MICROFINANCE INSTITUTIONS FULFILL THEIR PROMISE? EVIDENCE FROM CROSS-COUNTRY DATA. Applied Economics, 48, 16551677.

[27] Mazumder, M. S. U., \& Lu, W. (2015). WHAT IMPACT DOES MICROFINANCE HAVE ON RURAL LIVELIHOOD? A COMPARISON OF GOVERNMENTAL AND NONGOVERNMENTAL MICROFINANCE PROGRAMS IN BANGLADESH. World Development, 68, 336-354. doi:10.1016/j.worlddev.2014.12.002

[28] McIntosh, C., Villaran, G., \& Wydick, B. (2011a). MICROFINANCE AND HOME IMPROVEMENT: USING RETROSPECTIVE PANEL DATA TO MEASURE PROGRAM EFFECTS ON FUNDAMENTAL EVENTS. World Development, 39, 922-937.

[29] McIntosh, C., Villaran, G., \& Wydick, B. (2011b). MICROFINANCE AND HOME IMPROVEMENT: USING RETROSPECTIVE PANEL DATA TO MEASURE PROGRAM EFFECTS ON FUNDAMENTAL EVENTS. World Development, 39, 922-937.

[30] Mknelly, B., \& Dunford, C. (2000). IMPACT OF CREDIT WITH EDUCATION ON MOTHERS AND THEIR YOUNG CHILDREN'S NUTRITION: LOWER PRA RURAL BANK CREDIT WITH EDUCATION PROGRAM IN GHANA. Freedom from Hunger, 1-2.

[31] Morris, G., \& Barnes, C.. (2005). AN ASSESSMENT OF THE IMPACT OF MICROFINANCE. Journal of Microfinance, 7(1), 40-54.

[32] Nanor, M. A. (2008). MICROFINANCE AND ITS IMPACT ON SELECTED DISTRICTS IN EASTERN REGION OF GHANA. College of Art and Social Sciences, Kumasi. Kwame Nkrumah University of Science and Technology.

[33] Nawaz, S. (2010). MICROFINANCE AND POVERTY REDUCTION: EVIDENCE FROM A VILLAGE STUDY IN BANGLADESH. Journal of Asian and African Studies, 45, 670-683.

[34] Ngoasong, M. Z., \& Kimbu, A. N. (2016). INFORMAL MICROFINANCE INSTITUTIONS AND DEVELOPMENT-LED TOURISM ENTREPRENEURSHIP. Tourism Management, 52, 430-439. doi:10.1016/j.tourman.2015.07.012

[35] Ozturk, I. (2017). THE DYNAMIC RELATIONSHIP BETWEEN AGRICULTURAL SUSTAINABILITY AND FOOD-ENERGY-WATER POVERTY IN A PANEL OF SELECTED SUB-SAHARAN AFRICAN COUNTRIES. Energy Policy, 107, 289-299. doi:10.1016/j.enpol.2017.04.048

[36] Pronyk, P. M., Kim, J. C., Abramsky, T., Phetl, G., Hargreaves, J. R., \& Morison, L. A. (2008). A COMBINED MICROFINANCE AND TRAINING INTERVENTION CAN REDUCE HIV RISK BEHAVIOR IN YOUNG FEMALE PARTICIPANTS. AIDS, 22(13), 1659-1665.

[37] Raihan, S., Osmani, S. R., \& Khalily, M. A. B. (2017). THE MACRO IMPACT OF MICROFINANCE IN BANGLADESH: A CGE ANALYSIS. Economic Modelling, 62, 1-15. doi:10.1016/j.econmod.2017.01.002 
[38] Shimamura, Y., \& Lastarria-Cornhiel, S. (2009). CREDIT PROGRAM PARTICIPATION AND CHILD SCHOOLING IN RURAL MALAWI. World Development, 38(4), 567-580.

[39] Ssewamala, F. M., Ismayilova, L., McKay, M., Sperber, E., Bannon, W., \& Alice, S. (2010). GENDER AND THE EFFECTS OF AN ECONOMIC EMPOWERMENT PROGRAM ON ATTITUDES TOWARD SEXUAL RISK-TAKING AMONG AIDS ORPHANED ADOLESCENT YOUTH IN UGANDA. Journal of Adolescent Health, 46, 372-378.

[40] Tchakoute Tchuigoua, H. (2015). DETERMINANTS OF THE GOVERNANCE QUALITY OF MICROFINANCE INSTITUTIONS. The Quarterly Review of Economics and Finance, 58, 3243. doi:10.1016/j.qref.2015.02.011

[41] van Rooyen, C., Stewart, R., \& de Wet, T. (2012). THE IMPACT OF MICROFINANCE IN SUB-SAHARAN AFRICA: A SYSTEMATIC REVIEW OF THE EVIDENCE. World Development, 40(11), 2249-2262. doi:10.1016/j.worlddev.2012.03.012

[42] Wakoko, F. (2004). MICROFINANCE AND WOMEN'S EMPOWERMENT IN UGANDA: A socioeconomic approach. (Ph.D. Thesis), Ohio State University.

[43] Wijesiri, M. (2016). WEATHERING THE STORM: OWNERSHIP STRUCTURE AND PERFORMANCE OF MICROFINANCE INSTITUTIONS IN THE WAKE OF THE GLOBAL FINANCIAL CRISIS. Economic Modelling, 57, 238-247. doi:10.1016/j.econmod.2016.05.011

[44] Wijesiri, M., \& Meoli, M. (2015). PRODUCTIVITY CHANGE OF MICROFINANCE INSTITUTIONS IN KENYA: A BOOTSTRAP MALMQUIST APPROACH. Journal of Retailing and Consumer Services, 25, 115-121. doi:10.1016/j.jretconser.2015.04.004

\footnotetext{
*Corresponding author.

E-mail address: isabellemusanganya@yahoo.fr
} 